\title{
Epidemiology and Molecular Characterization of Rotavirus $A$ in Fruit Bats in Bangladesh
}

\author{
Ariful Islam, ${ }^{1,2}$ Mohammad Enayet Hossain, ${ }^{3}$ Melinda K. Rostal, ${ }^{1}$ Jinnat Ferdous, ${ }^{1,4}$ \\ Ausraful Islam, ${ }^{3}$ Rashedul Hasan, ${ }^{3}$ Mojnu Miah, ${ }^{3}$ Mustafizur Rahman, ${ }^{3}$ \\ Mohammed Ziaur Rahman, ${ }^{3}$ Peter Daszak, ${ }^{1}$ and Jonathan H. Epstein ${ }^{1}$ \\ ${ }^{1}$ EcoHealth Alliance, 460 West 34th Street, Suite 17, New York, NY 10001 \\ ${ }^{2}$ Centre for Integrative Ecology, School of Life and Environmental Sciences, Deakin University, Geelong, VIC, Australia \\ ${ }^{3}$ International Centre for Diarrheal Diseases Research, Bangladesh (icddr,b), Dhaka, Bangladesh \\ ${ }^{4}$ Institute of Epidemiology, Disease Control and Research (IEDCR), Mohakhali, Dhaka 1212, Bangladesh
}

\begin{abstract}
Rotavirus A (RVA) is the primary cause of acute dehydrating diarrhea in human and numerous animal species. Animal-to-human interspecies transmission is one of the evolutionary mechanisms driving rotavirus strain diversity in humans. We screened fresh feces from 416 bats (201 Pteropus medius, 165 Rousettus leschenaultii and 50 Taphozous melanopogon) for RVA using rRT-PCR. We detected a prevalence of 7\% (95\% CI 3.5-10.8) and 2\% (95\% CI 0.4-5.2) in P. medius and R. leschenaultii, respectively. We did not detect RVA in the insectivorous bat (T. melanopogon). We identified RVA strains similar to the human strains of G1 and G8 based on sequence-based genotyping, which underscores the importance of including wildlife species in surveillance for zoonotic pathogens to understand pathogen transmission and evolution better.
\end{abstract}

Keywords: Rotavirus A, Pteropus medius, Rousettus leschenaultii, Taphozous melanopogon, G1, G8

Globally, group A rotavirus (RVAs) is the primary cause of acute dehydrating diarrhea in people, especially in children (Karampatsas et al. 2018). It also causes disease in a number of animal species (Dhama et al. 2009). RVAs are estimated to cause 215,000 deaths per year globally in children ( $<5$ years) (Tate et al. 2016). There is a significant amount of RVA strain diversity, and a variety of human strains share genetic and antigenic features with animal origin RVA strains (Luchs and Timenetsky 2014). Interspecies transmission is an important mechanism of RVA evolution and can contribute to the diversity of hu-

Published online: September 2, 2020

Correspondence to: Jonathan H. Epstein, e-mail: epstein@ecohealthalliance.org man RVA strains (Do et al. 2016). However, heterologous RVA infections (such as a bovine RVA isolate infecting other species) have typically resulted in lower viral titers and an absence of severe diarrhea (Sieg et al. 2015) in people.

Approximately $60 \%$ of emerging infectious diseases are zoonotic, and the majority of those (72\%) originate in wildlife (Jones et al. 2008). Bats are believed to be the reservoir of RVA (He et al. 2017). RVA was found in two straw-colored fruit bats (Eidolon helvum) and an Egyptian fruit bat (Rousettus aegyptiacus) in Zambia (Sasaki et al. 2018); three E. helvum, a lesser mouse-tailed bat (Rhinopoma hardwickii) and an Egyptian tomb bat (Taphozous perforatus) in Saudi Arabia (Mishra et al. 2019); and in 38 
(out of 305; 9.2\%) Brazilian bats (Asano et al. 2016). Other studies have identified novel strains of RVA genotype from different species of bats, of which some were closely related to human RVAs (Kim et al. 2016; Yinda et al. 2016).

The general prevalence of rotavirus in human and animals like cattle, buffalo, goat and chicken were reported to be $23.8 \%$ and $12-43 \%$, respectively, in Bangladesh (Samad 2013). A study in Bangladesh identified a human RVA strain in which the VP3 gene sequence was more closely related to an RVA strain previously found in goats (Ghosh et al. 2011), suggesting possible interspecies RVA transmission. Kumar and Malik (Kumar and Malik 2018) also indicated that reassortment facilitated the infection of calves with an RVA strain that had a G1 gene related to a human RVA, the evolution of an emerging pathogen, which could be a threat to public health (Ghosh et al. 2011). Though rotaviral diarrhea in humans is common in Bangladesh (Pecenka et al. 2017), there are few data regarding RVA and its genetic diversity and geographic distribution within bats of Bangladesh. The current study was conducted to detect RVA within several species of bats and assess their similarity to human strains.

The study was conducted under ethical approval from the International Centre for Diarrheal Disease Research, Bangladesh (icddr,b; protocol: 2008-074), and University of California, Davis (protocol: 16048). We collected noninvasive fecal samples $(n=416)$ during a four-year period (2011-14) from northwest Bangladesh. We collected 165 fecal samples from small fruit bats (Rousettus leschenaultii) in Dupadanga and Nolia, Rajbari district; 201 fecal samples from large fruit bat species (Indian flying fox; Pteropus medius) in Dhaka, Faridpur, Manikganj and Tangail districts; and 50 fecal samples from the insectivorous blackbearded tomb bat (Taphozous melanopogon) in Orakandi and Ramnagar, Rajbari district (Fig. 1).

We collected fecal samples between 3 and 6 am following the procedure described by Swift et al. 2018. The tubes containing sample and nuclease lysis buffer were stored in a liquid nitrogen Dewar (Princeton Cryogenics, NJ, USA) in the field until being transferred to a $-80^{\circ} \mathrm{C}$ freezer at laboratory. We tested fecal swabs for RVA RNA by real-time reverse transcription polymerase chain reaction (rRT-PCR) using NSP3-specific primers and probes using the AgPath-ID ${ }^{\mathrm{TM}}$ One-Step RT-PCR system (Ambion Inc. Austin, USA) according to Jothikumar et al. (2009). To identify the G and P genotype, we performed conventional reverse transcription polymerase chain reaction (RT-PCR) to amplify the VP7 and VP4 gene fragments using consensus primer pairs Beg9/End9 and Con2/Con3, respectively (Table 1), as described elsewhere (Islam et al. 2019; Rahman et al. 2007). We carried out RT-PCR using the QIAGEN ${ }^{\circledR}$ One-Step RT-PCR Kit (QIAGEN, Germany) according to the manufacturer's instructions. Nucleotide sequencing was carried out using the di-deoxynucleotide chain termination method with the ABI PRISM BigDye Terminator Cycle Sequencing Reaction kit v3.1 (Life Technologies Corp., Carlsbad, CA 92008 USA) in an automated genetic analyzer (ABI 3500xL).The electropherogram files of the nucleotide sequences were examined and edited using Chromas 2.23 (Technelysium).

We submitted the sequences from this study to GenBank under the accession numbers MK674285 and MK674286. Sequence similarity searches were performed using the Basic Local Alignment Search Tool (BLAST) server on the GenBank database. Sequences which had $100 \%$ query coverage and $98-99 \%$ identity were selected for phylogenetic analysis. Phylogenetic trees were constructed according to the maximum likelihood method using MEGA (Molecular Evolutionary Genetics Analysis) version 6.0 (Tamura et al. 2011). Genotypes were determined by submitting the sequences to online rotavirus genotyping tool RotaC (http://rotac.regatools.be/). We used STATA-13 (StataCorp, 4905, Lakeway Drive, College Station, Texas 77845, USA) software for statistical analysis. We expressed the results as prevalence and their 95\% confidence interval (CI).

Seven percent $(n=201 ; 95 \%$ CI $3-11)$ of P. medius and $2 \%(n=165 ; 95 \%$ CI $0-5)$ of $R$. leschenaultii were positive for RVA. No RVA RNA was detected in $T$. melanopogon (Table 2). 24\% ( $n=55$; $95 \%$ CI $13-37 \%)$ of P. medius sampled in Dhaka were found to carry RVA, whereas $P$. medius from all other sites were negative ( $n=146 ; 95 \%$ CI $0-2.5$ ) (Table 2).

G1 and G8 genotypes were detected via VP7 genotyping, which was successful for $13 \%(2 / 16)$ of the RNApositive samples. $\mathrm{P}$ genotyping was not successful. Both of the genotyped strains were detected in Dhaka City, Bangladesh. The sequence of the bat G1 and G8 genotypes had high similarity with the human RVA strains, 90\% and 97.7$98.7 \%$, respectively. The bat G8 genotype also had high similarity with bovine strains (94-98.7\%) from India and porcine strains (84.5\%) from South Korea (Fig. 2).

To the authors' knowledge, RVA has not previously been reported in bats from Bangladesh. Our study identified RVA strains in $P$. medius and $R$. leschenaultii. Sasaki et al. (2018) also identified RVA in Rossettus sp. ( $n=1$ out 


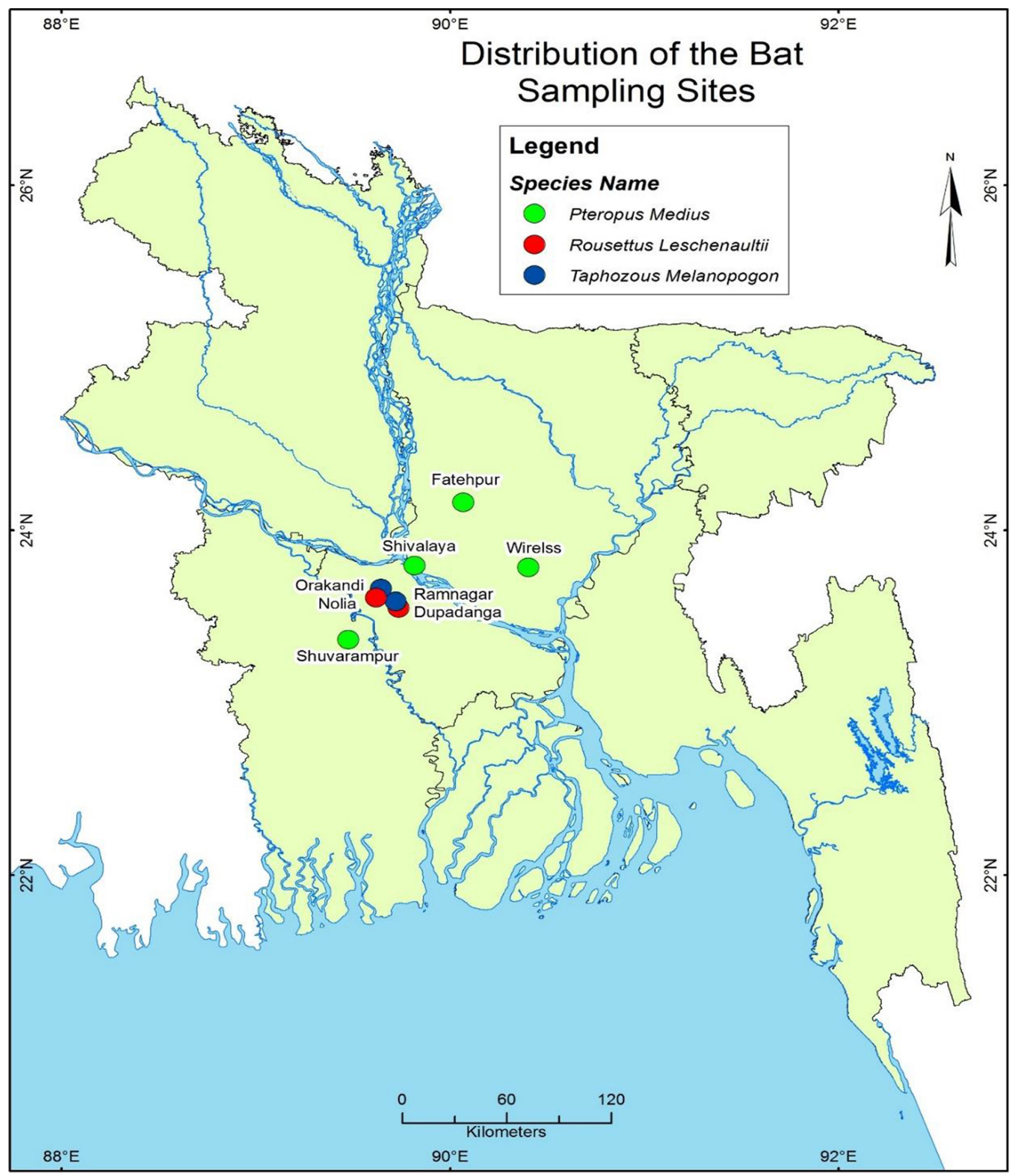

Figure 1. Distribution of the bat sampling locations from 2011 to 2014.

of 20), though it was a different species (R. aegyptiacus) from Zambia. Our study did not detect RVA RNA in Taphozous sp.; however, a previous study identified one $T$. perforatus $(n=1 / 17)$ carrying RVA in Saudi Arabia (Mis- hra et al. 2019). RVA was detected at a higher prevalence $(9.18 \% ; n=28 / 305)$ in bats from Brazil (Asano et al. 2016) and at lower prevalence $(0.7 \% ; n=4 / 457)$ from China (He et al. 2017) than our study. 


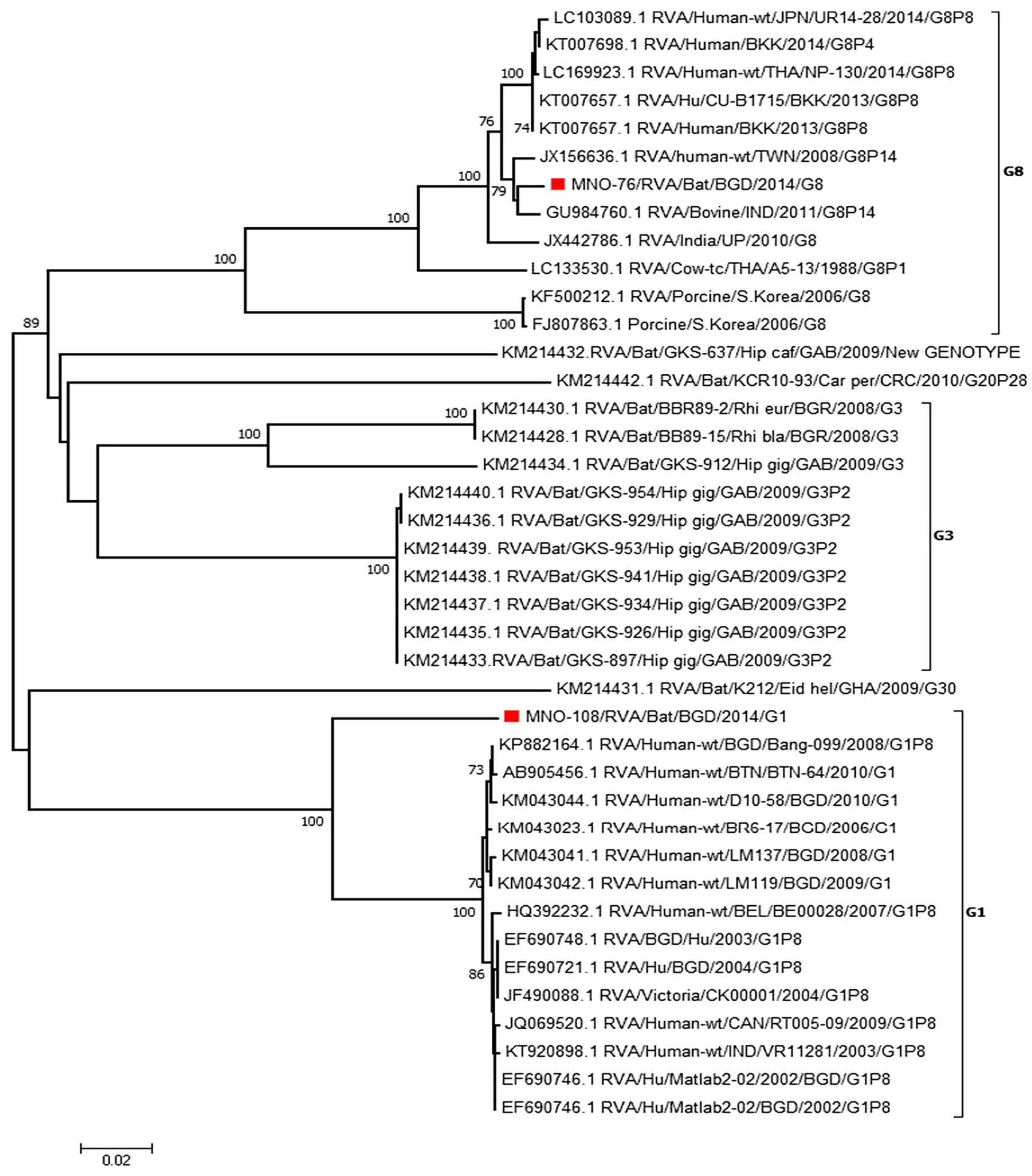

Figure 2. Phylogenetic trees based on partial nucleotide sequences of VP7. The bat RVA strains identified in this study were marked by red square (Color figure online).

The identification of genotypes related to human RVA strains suggests that anthropozoonotic transmission may be occurring between people and bats. While bat-specific RVAs have been identified (Jiang et al. 2004), the genetic sequences that we detected suggest that a reassortment event may have occurred. Habitat destruction and urbanization are hypothesized to drive increasing interactions between people and bat species (Kung et al. 2015). Pteropus 
Table 1. Oligonucleotide primers used in the study for PCR amplification.

\begin{tabular}{llllll}
\hline Primer & Type & Position & Strand & Sequence $\left(5^{\prime}-3^{\prime}\right)$ & References \\
\hline Forward & JVKF & $17-39$ & Plus & CAGTGGTTGATGCTCAAGATGGA & Jothikumar et al. (2009) \\
Reverse & JVKR & $147-123$ & minus & TCATTGTAATCATATTGAATACCCA & Jothikumar et al. (2009) \\
Probe & JVKP & $96-72$ & Plus & FAM-ACAACTGCAGCTTCAAAAGAAGWGT-BHQ1 & Jothikumar et al. (2009) \\
Beg9 & VP7 & $1-28$ & Plus & GGCTTTAAAAGAGAGAATTTCCGTCTGG & Farkas et al. 2008 \\
End9 & VP7 & $1062-1036$ & Minus & GGTCACATCATACAATTCTAATCTAAG & Farkas et al. (2008) \\
Con2 & VP4 & $868-887$ & Minus & ATTTCGGACCATTTATAACC & Farkas et al. (2008) \\
Con3 & VP4 & $11-32$ & Plus & TGGCTTCGCCATTTTATAGACA & Farkas et al. (2008) \\
\hline
\end{tabular}

Table 2. Rotavirus A RNA detection in the feces of fruit bats of Bangladesh, 2011-2014.

\begin{tabular}{|c|c|c|c|c|c|}
\hline Species & Location & $N$ & Positive $n(\%)$ & $95 \% \mathrm{CI}$ & \\
\hline \multirow{4}{*}{ Pteropus medius } & Urban & Dhaka & 55 & $13(23.6)$ & $13-37$ \\
\hline & Rural & Faridpur & 11 & 0 & $0-28.5$ \\
\hline & & Manikganj & 75 & 0 & $0-4.8$ \\
\hline & & Tangail & 60 & 0 & $0-5.9$ \\
\hline Subtotal & & & 201 & $13(6.5)$ & $3.5-10.8$ \\
\hline \multirow[t]{2}{*}{ Rousettus leschenaultii } & Rural & Dupadanga & 5 & $1(20)$ & $0.5-71$ \\
\hline & & Nolia, Rajbari & 160 & $2(1.3)$ & $0.15-4.4$ \\
\hline Subtotal & & & 165 & $3(1.8)$ & $0.4-5.2$ \\
\hline \multirow[t]{2}{*}{ Taphozous melanopogon } & Rural & Orakandi, Rajbari & 30 & 0 & $0-11.5$ \\
\hline & & & 20 & 0 & $0-16.8$ \\
\hline Subtotal & & & 50 & - & $0-7.1$ \\
\hline Total & & & 416 & $16(3.8)$ & $2.21-6.2$ \\
\hline
\end{tabular}

bats are known to roost in proximity to people, which may require them to share food and water resources (Luskin 2010). Bats have been reported drinking from surface water reservoirs (Stier 2003) and have a habit of immersing their body in the water. In Bangladesh, human and livestock waste is often disposed of in water reservoirs, which can also be contaminated if rain water washes fecal material into the reservoir.

Further, leakage from sewage systems could also contaminate surface water (Parveen et al. 2008). It is possible that bats could acquire RVA infection while drinking water from contaminated water bodies. We previously identified Salmonella sp. in P. medius in Bangladesh and hypothesized that bat may have been infected via consuming contaminated water in close proximity to people and livestock (Islam et al. 2013).
The G1 strain of RVA that we detected in bats has primarily been isolated from people, both globally and in Bangladesh (Ahmed et al. 2010; Saudy et al. 2017). This genotype has also been detected in environmental water samples and bivalve shellfish samples (Kittigul et al. 2015), which supports our hypothesis that human RVA strains may contaminate local water sources. G1 has rarely been detected in animal species worldwide (Do et al. 2016), though it has previously been identified in cattle of India (Kumar and Malik 2018). This G1 strain has not previously been identified in a bat species, and though it is phylogenetically distinct from other G1 strains in people, they are 98-99\% identical.

G8 genotypes are commonly detected in people in Africa and rarely detected elsewhere in the world (Agbemabiese et al. 2015). This genotype was also detected in people in Hungary within a zoonotic strain of RVA that 
spread from sheep and goats to people (Marton et al. 2017). G8 has also previously been identified from several livestock species (Karayel et al. 2017; Alkan et al. 2012; Gouvea et al. 1994), roe deer (Jamnikar-Ciglenecki et al. 2017) and poultry (Beserra et al. 2014). The G8 genotype identified in this study is closely related to RVA strains detected in people, bovine and caprine species. It is also possible that transmission of the RVA from livestock to bat also occurs, as there is evidence for these bats being infected with bovine and avian coronaviruses (Anthony et al. 2013). Given the described habitat and water-sharing behavior among bats, humans and livestock, it is not surprising to identify this G8 genotype in bats. A previous study provided evidence of direct bovine to human transmission of the RVA G8 genotype (Komoto et al. 2016). Human-associated bocaviruses and coronaviruses have been previously identified in P. medius in Bangladesh (Anthony et al. 2013). Together, these results suggest the possibility of host switching or virus spillover of RVA from people to bats. But we are not removing the possibility of shedding of bats' own RVA in guano. So it needs further study to explore whether the RVAs detected in this study are their own virus or from an external source.

RVA is not known to be pathogenic to bats, and the ability to genotype RVA from bats may have been unsuccessful if the bats have a relatively low viral load, or only shed RVA in the feces at low levels. There were several limitations to our study. We only sampled three species of bats and had relatively small sample sizes for each species. The primers and probes that we used were not specifically designed to identify bat-associated RVA, but for identifying strains of RVA commonly found in human or environmental samples. Future studies should use assays designed to detect conserved regions of the RVA genome to avoid false positive and negative results. Future studies should be done using bat-specific primers or next-generation sequencing (NGS) followed by sequencing of other gene segments like VP6, NSP4, NSP1 and NSP5.

This study identifies a potentially significant human pathogen (RVA) in bats. This suggests that anthropozoonotic transmission may be occurring, which we hypothesize occurs via contaminated water sources. This study recommends that bats should be included when seeking to identify the pool of RVA strains that may reassert before spilling back over into humans.

\section{ACKNOWLEDGEMENTS}

We thank the Bangladesh Forest Department and the Ministry of Environment and Forest for permission to conduct this study. This work was supported by the United States Agency for International Development (USAID) Emerging Pandemic Threats PREDICT (Cooperative Agreement No. AID-OAA-A-14-00102) and by the National Institutes of Health; NIAID (Award 2R01TW005869). We are thankful to icddr,b and its core donors Governments of Bangladesh, Canada, Sweden and the UK for providing core/unrestricted support. We thank Emily. S. Gurley, Najmul Haider, Tapan Kumar Dey, Shafiqul Islam, Abdul Hai, Pitu Biswas and Gafur Sheikh for their contributions to this study.

\section{OPEn Access}

This article is licensed under a Creative Commons Attribution 4.0 International License, which permits use, sharing, adaptation, distribution and reproduction in any medium or format, as long as you give appropriate credit to the original author(s) and the source, provide a link to the Creative Commons licence, and indicate if changes were made. The images or other third party material in this article are included in the article's Creative Commons licence, unless indicated otherwise in a credit line to the material. If material is not included in the article's Creative Commons licence and your intended use is not permitted by statutory regulation or exceeds the permitted use, you will need to obtain permission directly from the copyright holder. To view a copy of this licence, visit http://creativec ommons.org/licenses/by/4.0/.

\section{REFERENCES}

Agbemabiese CA, Nakagomi T, Doan YH, Nakagomi O (2015) Whole genomic constellation of the first human G8 rotavirus strain detected in Japan. Infection, Genetics and Evolution 35:184-193. https://doi.org/10.1016/j.meegid.2015.07.033

Ahmed K, Ahmed S, Mitui MT, Rahman A, Kabir L, Hannan A, Nishizono A, Nakagomi O (2010) Molecular characterization of VP7 gene of human rotaviruses from Bangladesh. Virus Genes 40:347-356. https://doi.org/10.1007/s11262-010-0463-x

Alkan F, Gulyaz V, Timurkan MO, Iyisan S, Ozdemir S, Turan N, Buonavoglia C, Martella V (2012) A large outbreak of enteritis in goat flocks in Marmara, Turkey, by G8P[1] group A rotaviruses. Archives of Virology 157:1183-1187. https://doi.org/ 10.1007/s00705-012-1263-5 
Anthony SJ, Epstein JH, Murray KA, Navarrete-Macias I, Zambrana-Torrelio CM, Solovyov A, Ojeda-Flores R, Arrigo NC, Islam A, Khan SA (2013) A strategy to estimate unknown viral diversity in mammals. MBio 4:e00598-00513

Asano KM, Gregori F, Hora AS, Scheffer KC, Fahl WO, Iamamoto K, Mori E, Silva FDF, Taniwaki SA, Brandao PE (2016) Group A rotavirus in Brazilian bats: description of novel T15 and H15 genotypes. Archives of Virology 161:3225-3230. https://doi.org/ 10.1007/s00705-016-3010-9

Beserra LAR, Barbosa BRP, Bernardes NTCG, Brandao PE, Gregori $\mathrm{F}$ (2014) Occurrence and characterization of rotavirus $\mathrm{A}$ in broilers, layers, and broiler breeders from Brazilian poultry farms. Avian Diseases 58:153-157. https://doi.org/10.1637/ 10626-080513-ResNote.1

Dhama K, Chauhan R, Mahendran M, Malik S (2009) Rotavirus diarrhea in bovines and other domestic animals. Veterinary Research Communications 33:1-23. https://doi.org/10.1007/ s11259-008-9070-x

Do LP, Nakagomi T, Otaki H, Agbemabiese CA, Nakagomi O, Tsunemitsu H (2016) Phylogenetic inference of the porcine Rotavirus A origin of the human G1P[7] gene. Infection, Genetics and Evolution 40:205-213. https://doi.org/10.1016/ j.meegid.2016.03.001

Farkas T, Sestak K, Wei C, Jiang X (2008) Characterization of a rhesus monkey calicivirus representing a new genus of Caliciviridae. Journal of Virology 82:5408-5416; DOI: https://doi. org/10.1128/jvi.00070-08

Ghosh S, Paul SK, Hossain MA, Alam MM, Ahmed MU, Kobayashi N (2011) Full genomic analyses of two human G2P[4] rotavirus strains detected in 2005: identification of a caprinelike VP3 gene. Journal of General Virology 92:1222-1227. https:// doi.org/10.1099/vir.0.029868-0

Gouvea V, Santos N, do C Timenetsky M (1994) Identification of bovine and porcine rotavirus $\mathrm{G}$ types by PCR. Journal of Clinical Microbiology 32:1338-1340

He B, Huang X, Zhang F, Tan W, Matthijnssens J, Qin S, Xu L, Zhao Z, Yang L, Wang Q, Hu T, Bao X, Wu J, Tu C (2017) Group A rotaviruses in chinese bats: Genetic composition, serology, and evidence for bat-to-human transmission and reassortment. Journal of Virology 91; https://doi.org/10.1128/ jvi.02493-16 [Online April 5, 2017]

Islam A, Mikolon A, Mikoleit M, Ahmed D, Khan SU, Sharker MY, Hossain MJ, Islam A, Epstein JH, Zeidner N (2013) Isolation of Salmonella virchow from a fruit bat (Pteropus giganteus). EcoHealth 10:348-351. https://doi.org/10.1007/s10393013-0866-y

Islam A, Hossain ME, Haider N, Rostal MK, Mukharjee SK, Ferdous J, Miah M, Rahman M, Daszak P, Rahman MZ, Epstein $\mathrm{JH}$ (2019) Molecular characterization of group A rotavirus from rhesus macaque (Macaca mulatta) at human-wildlife interfaces in Bangladesh. Transboundary and Emerging Diseases 0:1-11; h ttps://doi.org/10.1111/tbed.13431

Jamnikar-Ciglenecki U, Kuhar U, Steyer A, Kirbis A (2017) Whole genome sequence and a phylogenetic analysis of the G8P[14] group A rotavirus strain from roe deer. BMC Veterinary Research 13:353; DOI: https://doi.org/10.1186/s12917-017-1280-4

Jiang B, McClure HM, Fankhauser RL, Monroe SS, Glass RI (2004) Prevalence of rotavirus and norovirus antibodies in nonhuman primates. Journal of Medical Primatology 33:30-33. https://doi.org/10.1111/j.1600-0684.2003.00051.x

Jones KE, Patel NG, Levy MA, Storeygard A, Balk D, Gittleman JL, Daszak P (2008) Global trends in emrging infectious diseases.
Nature 451(7181):990-993; https://doi.org/10.1038/nature0653 6

Jothikumar N, Kang G, Hill VR (2009) Broadly reactive TaqMan ${ }^{\circledR}$ assay for real-time RT-PCR detection of rotavirus in clinical and environmental samples. Journal of Virological Methods 155:126131. https://doi.org/10.1016/j.jviromet.2008.09.025

Karampatsas K, Osborne L, Seah ML, Tong CYW, Prendergast AJ (2018) Clinical characteristics and complications of rotavirus gastroenteritis in children in east London: A retrospective casecontrol study. PLoS One 13:e0194009; https://doi.org/10.1371/ journal.pone.0194009

Karayel I, Feher E, Marton S, Coskun N, Banyai K, Alkan F (2017) Putative vaccine breakthrough event associated with heterotypic rotavirus infection in newborn calves, Turkey, 2015. Veterinary Microbiology 201:7-13. https://doi.org/10.1016/j.vetmic.2016.12.028

Kim H, Yoon SW, Kim DJ, Koo BS, Noh J, Kim J, Choi Y, Na W, Chang KT, Song D (2016) Detection of Severe Acute Respiratory Syndrome-Like, Middle East Respiratory Syndrome-Like Bat Coronaviruses and Group H Rotavirus in Faeces of Korean Bats. Transboundary and Emerging Diseases 63:365-372. https:// doi.org/10.1111/tbed.12515

Kittigul L, Singhaboot Y, Chavalitshewinkoon-Petmitr P, Pombubpa K, Hirunpetcharat C (2015) A comparison of virus concentration methods for molecular detection and characterization of rotavirus in bivalve shellfish species. Food Microbiology 46:161-167. https://doi.org/10.1016/j.fm.2014.07.020

Komoto S, Adah MI, Ide T, Yoshikawa T, Taniguchi K (2016) Whole genomic analysis of human and bovine G8P[1] rotavirus strains isolated in Nigeria provides evidence for direct bovineto-human interspecies transmission. Infection, Genetics and Evolution 43:424-433. https://doi.org/10.1016/j.meegid.2016.06.023

Kumar N, Malik YS (2018) Molecular characterization of unusual bovine rotavirus A strains having high genetic relatedness with human rotavirus: evidence for zooanthroponotic transmission. Zoonoses and Public Health; https://doi.org/10.1111/zph.12452 [Online February 20, 2018]

Kung NY, Field HE, McLaughlin A, Edson D, Taylor M (2015) Flying-foxes in the Australian urban environment-community attitudes and opinions. One Health (Amsterdam, Netherlands) 1:24-30; https://doi.org/10.1016/j.onehlt.2015.07.002

Luchs A, Timenetsky MdCST (2014) G8P[6] rotaviruses isolated from Amerindian children in Mato Grosso do Sul, Brazil, during 2009: close relationship of the $G$ and $P$ genes with those of bovine and bat strains. Journal of General Virology 95:627641. https://doi.org/10.1099/vir.0.058099-0

Luskin MS (2010) Flying foxes prefer to forage in farmland in a tropical dry forest landscape mosaic in Fiji. Biotropica 42:246250. https://doi.org/10.1111/j.1744-7429.2009.00577.x

Marton S, Doro R, Feher E, Forro B, Ihasz K, Varga-Kugler R, Farkas SL, Banyai K (2017) Whole genome sequencing of a rare rotavirus from archived stool sample demonstrates independent zoonotic origin of human G8P[14] strains in Hungary. Virus Research 227:96-103. https://doi.org/10.1016/j.virusres.2016.09.012

Mishra N, Fagbo SF, Alagaili AN, Nitido A, Williams SH, Ng J, Lee B, Durosinlorun A, Garcia JA, Jain K, Kapoor V, Epstein JH, Briese T, Memish ZA, Olivial KJ, Lipkin WI (2019) A viral metagenomics survey identifies known and novel mammalian viruses in bats from Saudi Arabia. PLoS One 14:e0214227; h ttps://doi.org/10.1371/journal.pone.0214227 
Parveen S, Ahmed MSU, Nasreen T (2008) Microbial Contamination of water in around Dhaka city. Bangladesh Journal of Scientific and Industrial Research 43:273-276. https://doi.org/ 10.3329/bjsir.v43i2.972

Pecenka C, Parashar U, Tate JE, Khan JAM, Groman D, Chacko S, Shamsuzzaman M, Clark A, Atherly D (2017) Impact and costeffectiveness of rotavirus vaccination in Bangladesh. Vaccine 35:3982-3987. https://doi.org/10.1016/j.vaccine.2017.05.087

Rahman M, Sultana R, Ahmed G, Nahar S, Hassan ZM, Saiada F, Podder G, Faruque AS, Siddique A, Sack DA (2007) Prevalence of $\mathrm{G} 2 \mathrm{P}[4]$ and $\mathrm{G} 12 \mathrm{P}[6]$ rotavirus, Bangladesh. Emerging Infectious Diseases 13:18; DOI: https://dx.doi.org/10.3201\%2Fe id1301.060910

Samad M (2013) Public health threat caused by zoonotic diseases in Bangladesh. Bangladesh Journal of Veterinary Medicine 9:95120. https://doi.org/10.3329/bjvm.v9i2.13451

Sasaki M, Kajihara M, Changula K, Mori-Kajihara A, Ogawa H, Hangombe BM, Mweene AS, Simuunza M, Yoshida R, Carr M, Orba Y, Takada A, Sawa H (2018) Identification of group A rotaviruses from Zambian fruit bats provides evidence for longdistance dispersal events in Africa. Infection, Genetics and Evolutin 63:104-109. https://doi.org/10.1016/j.meegid.2018.05.016

Saudy N, Elshabrawy WO, Megahed A, Foad MF, Mohamed AF (2017) Genotyping and clinicoepidemiological characterization of rotavirus acute gastroenteritis in egyptian children. Polish Journal of Microbiology 65:433-442

Sieg M, Ruckner A, Kohler C, Burgener I, Vahlenkamp TW (2015) A bovine G8P[1] group A rotavirus isolated from an asymp- tomatically infected dog. Journal of General Virology 96:106-114. https://doi.org/10.1099/vir.0.069120-0

Stier SC (2003) Dietary habits of two threatened co-roosting flying foxes (Megachiroptera) Subic Bay Philippines: A Graduate Student Theses Paper. University of Montana, Paper no. 6513. Available: https://scholarworks.umt.edu/cgi/viewcontent.cgi?art icle $=7548 \&$ context $=$ etd [accessed April 3, 2018]

Swift JF, Lance RF, Guan X, Britzke ER, Lindsay DL, Edwards CE (2018) Multifaceted DNA metabarcoding: Validation of a noninvasive, next-generation approach to studying bat populaitons. Evolutionary Application 11(7):1120-1138; https://doi. org/10.1111/eva.12644

Tamura K, Peterson D, Peterson N, Stecher G, Nei M, Kumar S (2011) MEGA5: molecular evolutionary genetics analysis using maximum likelihood, evolutionary distance, and maximum parsimony methods. Molecular Biology and Evolution 28:27312739. https://doi.org/10.1093/molbev/msr121

Tate JE, Burton AH, Boschi-Pinto C, Parashar UD (2016) Global, regional, and national estimates of rotavirus mortality in children $<5$ years of age, 2000-2013. Clinical Infectious Diseases 62 Suppl 2:S96-S105; https://doi.org/10.1093/cid/civ1013

Yinda CK, Zeller M, Conceicao-Neto N, Maes P, Deboutte W, Beller L, Heylen E, Ghogomu SM, Ranst VM, Matthijnssens J (2016) Novel highly divergent reassortant bat rotaviruses in Cameroon, without evidence of zoonosis. Scientific reports 6; DOI: https://doi.org/10.1038/srep34209 